\title{
The way of serum chromium utilization may contribute to cardiovascular risk factors in centrally obese persons
}

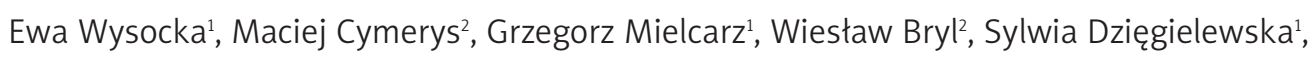
Lech Torliński ${ }^{1}$

\begin{abstract}
${ }^{1}$ Chair of Chemistry and Clinical Biochemistry, Department of Clinical Biochemistry and Laboratory Medicine, University of Medical Sciences, Poznan, Poland

2Department of Internal Medicine, Hypertension and Metabolic Disorders, University of Medical Sciences, Poznan, Poland
\end{abstract}

Submitted: 18 January 2011

Accepted: 13 February 2011

Arch Med Sci 2011; 7, 2: 257-263

DOI: 10.5114 /aoms.2011.22076

Copyright (c) 2011 Termedia \& Banach

\section{Abstract}

Introduction: Obesity-related disturbances are considered to be risk factors for cardiovascular disease (CVD). Chromium is shown to improve carbohydrate and lipid metabolism. Conflicting data on effects of chromium supplementation in humans are published. The aim of the study was to assess the concentrations of serum chromium during the 75 -g oral glucose tolerance test (OGTT) in obese persons.

Material and methods: Fourty-eight centrally obese Caucasians, apparently healthy, using neither special diet nor mineral supplementation, were enrolled in the study. During the OGTT, 0-min and 120-min concentrations of plasma glucose (G 0', G 120'), serum insulin (Ins 0', Ins 120') and chromium (Cr 0', Cr 120') were determined. Plasma lipids, apolipoproteins $A$ and $B$, and serum uric acid were measured at 0 min only. For parameters assessed during the OGTT, the difference $\mathrm{D}=\left[\left(120^{\prime}\right.\right.$ concentration $)-\left(0^{\prime}\right.$ concentration $\left.)\right]$ was calculated. Contradictory tendencies of $\mathrm{Cr} 120^{\prime}$ were observed; thus the difference of serum chromium concentrations, $\mathrm{DCr}=\left[\left(\mathrm{Cr} 120^{\prime}\right)-\left(\mathrm{Cr} 0^{\prime}\right)\right]$, was used to establish the positive $\mathrm{DCr}$ group with $\mathrm{DCr}>0$ (PosDCr: $n=24 ; 9$ male/15 female) and the negative DCr group with $\mathrm{DCr}<0$ (NegDCr: $n=24 ; 8$ male/16 female).

Results: The studied groups were comparable as far as their metabolic parameters are concerned, except higher G 120' $(p=0.043)$ and DG $(p=0.048)$, and lower $\mathrm{Cr} 120$ ' $(p<0.000)$, which were observed in the NegDCr group. The NegDCr persons showed inverse correlations between $\mathrm{Cr} \mathrm{O}^{\prime}$ and systolic and diastolic blood pressure.

Conclusions: We suggest that the studied centrally obese persons differed in chromium metabolism. In subjects "consuming" Cr during the OGTT, chromium status may be associated with increased risk for CVD.

Key words: abdominal obesity, trace element, blood pressure, glucose.

\section{Introduction}

Central obesity is considered to be a risk factor for type 2 diabetes and cardiovascular disease (CVD). The coexistence of obesity, hypertension, and lipid and glucose abnormalities is under worldwide discussion, composing definition of the metabolic syndrome [1]. The increasing prevalence of overweight and obesity in humans all over the world stresses the importance of obesity-related disturbances [2]. Confirmed activities

\author{
Corresponding author: \\ Ewa Wysocka MD, PhD \\ Chair of Chemistry \\ and Clinical Biochemistry \\ Department \\ of Clinical Biochemistry \\ and Laboratory Medicine \\ University of Medical \\ Sciences \\ 6 Grunwaldzka \\ 60-780 Poznan, Poland \\ Phone: +48 618546590 \\ Fax: +48 618546599 \\ E-mail: ewysocka@ump.edu.pl
}


and new insights to prevent the development of metabolic abnormalities and subsequent CVD in humans are needed $[3,4]$.

Chromium was discovered to improve carbohydrate and lipid metabolism, especially in type 2 diabetics. This trace element may regulate insulin action and facilitate glucose transfer into cells. Much lower amounts of the hormone are required, since chromium increases insulin efficiency $[5,6]$. The hypothesis of serum chromium statement sharing insulin action in insulin-sensitive cells is presented in Figure 1.

Chromium exists in our environment in several oxidation states, including metallic $\left(\mathrm{Cr}^{0}\right)$; trivalent $\left(\mathrm{Cr}^{+3}\right)$ - a predominant stable biological form; and hexavalent $\left(\mathrm{Cr}^{+6}\right)-$ a strong oxidizing agent, highly toxic [7]. Some controversies have been published about serum chromium concentrations in healthy persons, for years. Reported values vary from 0.9-3.0 nmol// to 2.4-4.7 nmol// [8]. About $9.0 \mathrm{nmol} / \mathrm{l}$ serum chromium concentration was observed in babies, which declined until 5.0-6.0 nmol/l in adults and elderly, and decreased more in type 2 diabetic patients to $3.8 \mathrm{nmol} / \mathrm{l}$ [9]. Nowadays nutrients might not provide appropriate doses of trace elements. Postindustrial environmental changes and new nutritional habits, such as highly refined and processed food, can result in chromium deficiency in particular [10].

Decreased serum chromium levels are observed in patients with diabetes [11]. We were interested in the conflicting data reporting either a lack of effect [12] or significant improvement [13] on carbohydrate and lipid metabolism under chromium supplementation. Furthermore, we realized the potential influence of this trace element on insulin sensitivity, which inspired us to plan this research.

The aim of the study was to assess concentrations of serum chromium during the oral glucose tolerance test and their relations to blood pressure and some metabolic factors in centrally obese persons.

\section{Material and methods}

\section{Subjects and settings}

The study was performed in accordance with the Declaration of Helsinki for human research and the study protocol was approved by the Bioethical Committee of Poznan University of Medical Sciences. The subjects participating in the study gave informed consent to the study procedure.

Non-smoking adult Caucasians, residents of Poznan city, without any acute disease or chronic disorder but centrally obese according to the International Diabetes Federation (IDF) 2005 criteria regarding waist circumference of at least $94 \mathrm{~cm}$ for males and at least $80 \mathrm{~cm}$ for females [1, 2], were invited to the study. Both females and males using no special diet or mineral supplementation underwent the study procedure and were qualified

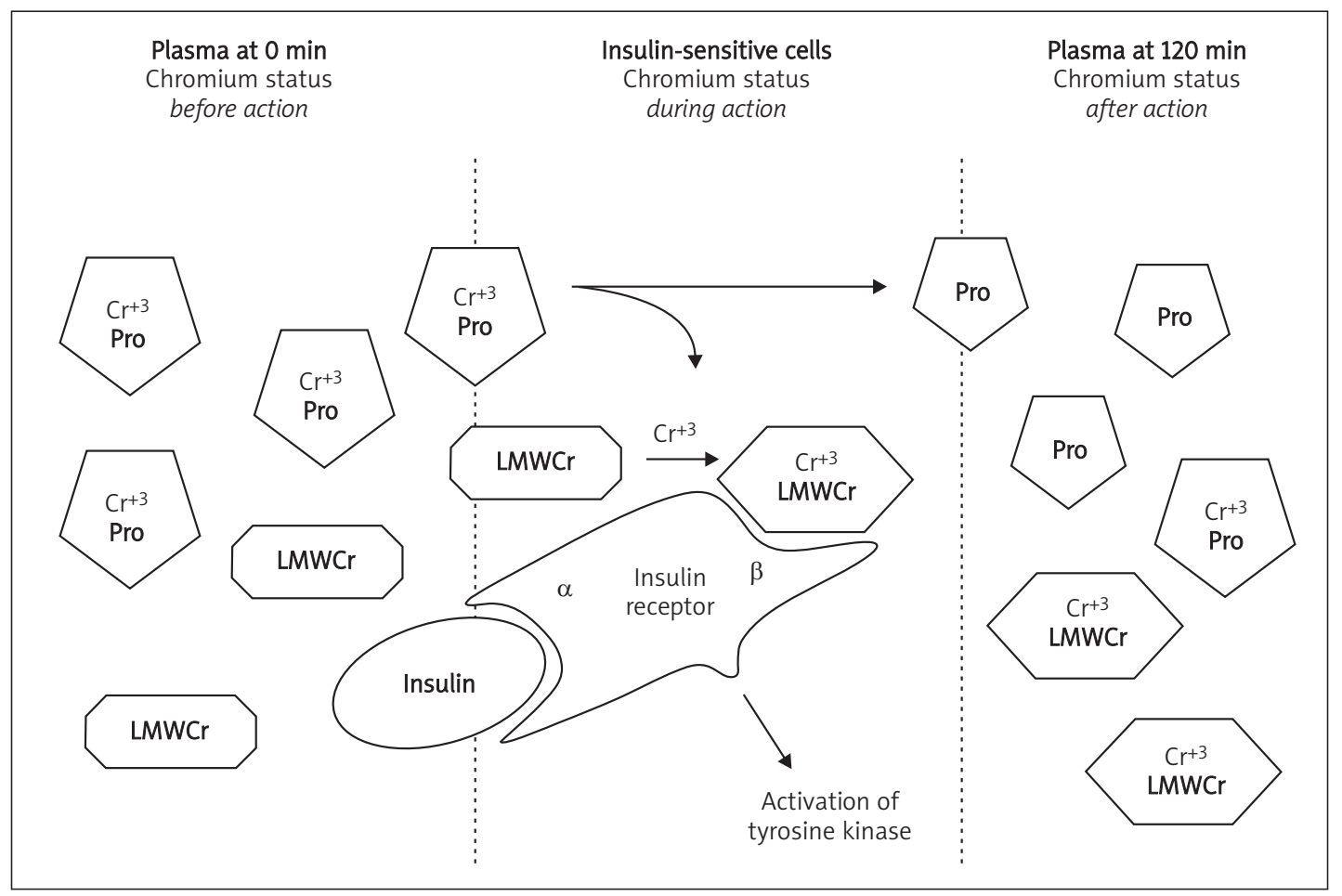

Figure 1. The hypothesis of chromium metabolism during the oral glucose tolerance test

$\mathrm{Cr}^{+3}$ - trivalent chromium, Pro - plasma protein (most likely transferrin), LMWCr - low molecular weight chromium binding substance, $\alpha, \beta-\alpha$ and $\beta$ subunits of insulin receptor 
for the 75-g oral glucose tolerance test (OGTT) according to WHO recommendations [14]

Finally 48 persons (17 males, 31 females) aged from 25 to 65 years old, since the difference of serum chromium concentrations ( $\mathrm{DCr}$ ) had been calculated during the OGTT, were categorized into two groups of subjects: the positive DCr group, PosDCr ( $n=24,9$ males, 15 females), and the negative DCr group, NegDCr $(n=24,8$ males, 16 females).

\section{Measurements}

The complete physical examination, including the systolic (SBP) and diastolic arterial blood pressure (DBP), the measurement of waist circumference $(\mathrm{cm})$, the body fat composition (\% fat, FAT) by bioimpedance using BodyStat equipment and the calculation of body mass index $\left(\mathrm{BMI}=\mathrm{kg} / \mathrm{m}^{2}\right)$ were performed. The arterial blood pressure was assessed twice on the left arm with an appropriate cuff size, using the sphygmomanometer MEDEL Palm Pro 91431 (Medel, Italy), after at least 15 min' rest in a sitting position, and the result was expressed as the mean value of two measurements.

The studied persons underwent collection of ulnar venous blood twice: fasting at 0 min ( $\left.0^{\prime}\right)$ and at $120 \mathrm{~min}\left(120^{\prime}\right)$ of the $75-\mathrm{g}$ OGTT. During the OGTT concentrations of plasma glucose $(\mathrm{G})$, serum insulin (Ins) and chromium ( $\mathrm{Cr}$ ) were determined twice (0' and 120'). Plasma total cholesterol (T-C), HDL cholesterol (HDL-C), triglycerides (TG), apolipoprotein A (apo A), apolipoprotein B (apo B) and uric acid (UA) were assessed fasting. LDL cholesterol (LDL-C) was calculated according to the Friedewald formula, $\mathrm{LDL}-\mathrm{C}[\mathrm{mmol} / \mathrm{l}]=[(\mathrm{T}-\mathrm{C})-(\mathrm{HDL}-\mathrm{C})-(\mathrm{TAG} / 2,2)]$.

Plasma glucose, lipids and uric acid concentrations were determined by enzymatic methods, and apo $A$ and apo B were measured by an immunoenzymatic method, on a Dimension Xpand Plus integrated analyser (Siemens Healthcare, USA). The reference sera level 1 and level 2 (Randox, United Kingdom) were used for monitoring the accuracy of the determinations.

Fasting serum samples designated for insulin and chromium measurements were frozen and stored at $-25^{\circ} \mathrm{C}$ until assayed, separately.

Serum insulin was measured by the ELISA method (BioSource, Belgium) on a microplate reader (Sunrise Tecan, Switzerland), with a sensitivity of $0.15 \mathrm{mIU} / \mathrm{l}$. The intra-assay coefficient of variation (CV) and inter-assay CV for insulin measurements were calculated as $3.5 \%$ and $4.3 \%$, respectively. Insulin resistance indices, i.e. the insulin resistance ratio, $I R=(I n s / G$ O' $[\mathrm{mg} / \mathrm{dl}])$, and Homeostatic Model Assessment for Insulin Resistance, HOMA-IR = $\left(\mathrm{GO}[\mathrm{mmol} / \mathrm{l}]^{*} \mathrm{Ins} / 22,5\right)$, were calculated.
Serum chromium concentration was determined using graphite furnace atomic absorption spectroscopy (Perkin Elmer Zeeman 3030 spectrometer, PerkinElmer Instruments, USA) with intra-assay CV of $4.2 \%$. The reference sera Seronorm ${ }^{T M}$ Trace Elements Serum level 1 and level 2 (Sero AS, Norway) were used for monitoring the accuracy of the determinations.

For parameters determined during the OGTT, the difference $D=\left\{\left(120^{\prime}\right.\right.$ concentration $)$ ( 0 ' concentration) $\}$ was calculated. Contradictory directions of serum Cr 120' concentrations were observed and the difference of serum chromium concentrations, $\mathrm{DCr}=\left(\left[\mathrm{Cr} 120^{\prime}\right]-\left[\mathrm{Cr} 0^{\prime}\right]\right)$, was used to establish the positive $\mathrm{DCr}$ group with $\mathrm{DCr}>0$ (PosDCr: $n=24,9$ male/15 female) and the negative DCr group with DCr < 0 (NegDCr: $n=24,8$ male/16 female).

\section{Statistical analysis}

Statistical calculations were performed using the program Statistica 6.0 for Windows. The normality of value distributions was checked by Shapiro-Wilk test. Significant differences between studied groups were calculated by nonparametric Mann-Whitney $U$ test and correlations were described by Spearman's coefficient (R), while $p<0.05$. All results are shown as mean \pm standard deviation and median (in parentheses).

\section{Results}

The characteristics of subjects with respect to their gender revealed no differences between males and females, except FAT and waist, which is in accordance with gender-related body mass composition and body fat distribution, and Ins 120' and DIns both higher in the female group. The details are presented in Table I. The whole study population exhibited a decreased tendency for serum $\mathrm{Cr}$ concentration as compared with literature reference values obtained from normal body mass and normal glucose tolerance persons, but remaining within ranges for humans in general $[8,9]$.

Following the aim of the study, persons were categorized according to a positive (PosDCr) or negative (NegDCr) difference of serum chromium concentrations during the OGTT. The clinical and laboratory data of the studied groups are shown in Table II.

In the PosDCr group 58\% normal and 42\% newly diagnosed abnormal glucose tolerance (dysglycaemia) subjects were diagnosed, while in the NegDCr group, $46 \%$ and 54\% were diagnosed, respectively. The exact data are presented in Table III.

The NegDCr persons demonstrated higher G120', lower $\mathrm{Cr} 120$ ' and $\mathrm{DCr}$ compared with PosDCr persons. 
Table I. Characteristics of the study population comparison between males and females investigated. Data are presented as mean \pm standard deviation and median (in parentheses)

\begin{tabular}{|c|c|c|c|}
\hline Parameters & $\begin{array}{l}\text { Males } \\
(n=17)\end{array}$ & $\begin{array}{l}\text { Females } \\
(n=31)\end{array}$ & $\begin{array}{l}\text { Significant } \\
\text { difference }\end{array}$ \\
\hline Age [years] & $\begin{array}{c}46.2 \pm 10.6 \\
(48.0)\end{array}$ & $\begin{array}{c}49.4 \pm 10.2 \\
\quad(52.0)\end{array}$ & \\
\hline $\mathrm{BMI}\left[\mathrm{kg} / \mathrm{m}^{2}\right]$ & $\begin{array}{c}34.8 \pm 6.9 \\
(34.1)\end{array}$ & $\begin{array}{c}36.6 \pm 6.5 \\
(35.3)\end{array}$ & \\
\hline Waist $[\mathrm{cm}]$ & $\begin{array}{c}118.9 \pm 17.7 \\
(116.0)\end{array}$ & $\begin{array}{c}109.9 \pm 14.9 \\
(107.0)\end{array}$ & $p=0.045$ \\
\hline FAT [\%] & $\begin{array}{c}35.6 \pm 5.2 \\
(34.6)\end{array}$ & $\begin{array}{c}46.3 \pm 7.7 \\
(46.9)\end{array}$ & $p=0.000$ \\
\hline $\mathrm{SBP}[\mathrm{mmHg}]$ & $\begin{array}{c}138.6 \pm 11.0 \\
(140.0)\end{array}$ & $\begin{array}{c}143.9 \pm 21.4 \\
(150.0)\end{array}$ & \\
\hline $\mathrm{DBP}[\mathrm{mmHg}]$ & $\begin{array}{c}88.5 \pm 7.9 \\
(90.0)\end{array}$ & $\begin{array}{c}92.3 \pm 11.1 \\
(90.0)\end{array}$ & \\
\hline $\mathrm{G} 0^{\prime}[\mathrm{mmol} / \mathrm{l}]$ & $\begin{array}{l}5.79 \pm 1.70 \\
\quad(5.14)\end{array}$ & $\begin{array}{c}5.52 \pm 0.72 \\
\quad(5.40)\end{array}$ & \\
\hline G 120' $[\mathrm{mmol} / \mathrm{l}]$ & $\begin{array}{c}6.82 \pm 3.32 \\
(6.34)\end{array}$ & $\begin{array}{c}7.31 \pm 2.73 \\
(6.84)\end{array}$ & \\
\hline $\mathrm{DG}[\mathrm{mmol} / \mathrm{l}]$ & $\begin{array}{c}1.03 \pm 2.05 \\
(1.22)\end{array}$ & $\begin{array}{c}1.79 \pm 2.19 \\
(1.35)\end{array}$ & \\
\hline Ins 0' [mU/l] & $\begin{array}{c}54.0 \pm 56.3 \\
(21.9)\end{array}$ & $\begin{array}{c}40.9 \pm 28.3 \\
(29.4)\end{array}$ & \\
\hline Ins $120^{\prime}[\mathrm{mU} / \mathrm{l}]$ & $\begin{array}{c}137.5 \pm 152.6 \\
(80.8)\end{array}$ & $\begin{array}{c}209.6 \pm 165.1 \\
(142.7)\end{array}$ & $p=0.045$ \\
\hline DIns [mU/l] & $\begin{array}{c}83.5 \pm 138.0 \\
(30.5)\end{array}$ & $\begin{array}{c}168.7 \pm 159.9 \\
(98.2)\end{array}$ & $p=0.036$ \\
\hline IR (Ins O'/G 0') & $\begin{array}{c}0.550 \pm 0.635 \\
(0.230)\end{array}$ & $\begin{array}{l}0.418 \pm 0.281 \\
\quad(0.297)\end{array}$ & \\
\hline HOMA-IR & $\begin{array}{c}14.4 \pm 16.9 \\
(5.6)\end{array}$ & $\begin{array}{c}10.0 \pm 7.4 \\
(7.7)\end{array}$ & \\
\hline $\mathrm{T}-\mathrm{C}[\mathrm{mmol} / \mathrm{l}]$ & $\begin{array}{l}5.51 \pm 0.85 \\
\quad(5.43)\end{array}$ & $\begin{array}{c}5.47 \pm 1.11 \\
\quad(5.28)\end{array}$ & \\
\hline TAG [mmol/l] & $\begin{array}{c}1.99 \pm 0.97 \\
(1.86)\end{array}$ & $\begin{array}{c}1.61 \pm 0.77 \\
(1.50)\end{array}$ & \\
\hline $\mathrm{HDL}-\mathrm{C}[\mathrm{mmol} / \mathrm{l}]$ & $\begin{array}{c}1.41 \pm 0.99 \\
\quad(1.19)\end{array}$ & $\begin{array}{c}1.26 \pm 0.29 \\
\quad(1.22)\end{array}$ & \\
\hline LDL-C [mmol/l] & $\begin{array}{c}3.38 \pm 0.71 \\
(3.44)\end{array}$ & $\begin{array}{c}3.049 \pm 1.09 \\
(3.19)\end{array}$ & \\
\hline Apo A [mg/dl] & $\begin{array}{c}117.2 \pm 42.2 \\
(131.6)\end{array}$ & $\begin{array}{c}131.6 \pm 37.2 \\
(132.9)\end{array}$ & \\
\hline Apo B [mg/dl] & $\begin{array}{c}116.7 \pm 20.7 \\
(117.1)\end{array}$ & $\begin{array}{c}113.5 \pm 21.7 \\
(109.1)\end{array}$ & \\
\hline $\mathrm{U} A[\mu \mathrm{mol} / \mathrm{l}]$ & $\begin{array}{c}330.1 \pm 103.8 \\
(346.2)\end{array}$ & $\begin{array}{c}314.6 \pm 80.1 \\
(318.8)\end{array}$ & \\
\hline $\mathrm{Cr} 0^{\prime}[\mathrm{nmol} / \mathrm{l}]$ & $\begin{array}{c}2.76 \pm 0.29 \\
(2.85)\end{array}$ & $\begin{array}{c}2.86 \pm 0.23 \\
(2.92)\end{array}$ & \\
\hline $\mathrm{Cr} 120^{\prime}[\mathrm{nmol} / \mathrm{l}]$ & $\begin{array}{c}2.79 \pm 0.53 \\
(2.71)\end{array}$ & $\begin{array}{c}3.03 \pm 0.85 \\
(2.88)\end{array}$ & \\
\hline $\mathrm{DCr}[\mathrm{nmol} / \mathrm{ll}]$ & $\begin{array}{c}0.037 \pm 0.66 \\
(0.21)\end{array}$ & $\begin{array}{c}0.17 \pm 0.89 \\
(-0.02)\end{array}$ & \\
\hline
\end{tabular}

Table II. Characteristics of the studied groups. Data are presented as mean \pm standard deviation and median (in parentheses)

\begin{tabular}{|c|c|c|c|}
\hline Parameters & $\begin{array}{l}\text { Pos DCr } \\
(n=24)\end{array}$ & $\begin{array}{l}\text { Neg DCr } \\
(n=24)\end{array}$ & $\begin{array}{l}\text { Significant } \\
\text { difference }\end{array}$ \\
\hline Age [years] & $\begin{array}{c}48.7 \pm 11.3 \\
\quad(52.0)\end{array}$ & $\begin{array}{c}47.9 \pm 9.5 \\
(49.5)\end{array}$ & \\
\hline $\mathrm{BMI}\left[\mathrm{kg} / \mathrm{m}^{2}\right]$ & $\begin{array}{c}35.5 \pm 5.6 \\
(34.6)\end{array}$ & $\begin{array}{c}36.4 \pm 7.7 \\
(35.6)\end{array}$ & \\
\hline Waist $[\mathrm{cm}]$ & $\begin{array}{c}110.4 \pm 14.7 \\
(107.5)\end{array}$ & $\begin{array}{c}115.8 \pm 17.8 \\
(113.0)\end{array}$ & \\
\hline FAT [\%] & $\begin{array}{c}42.0 \pm 9.4 \\
(43.1)\end{array}$ & $\begin{array}{c}43.0 \pm 8.0 \\
(43.3)\end{array}$ & \\
\hline $\mathrm{SBP}[\mathrm{mmHg}]$ & $\begin{array}{c}139.5 \pm 14.8 \\
(140.0)\end{array}$ & $\begin{array}{c}144.6 \pm 21.5 \\
(145.0)\end{array}$ & \\
\hline $\mathrm{DBP}[\mathrm{mmHg}]$ & $\begin{array}{c}90.5 \pm 9.4 \\
(90.0)\end{array}$ & $\begin{array}{c}91.5 \pm 11.1 \\
(90.0)\end{array}$ & \\
\hline $\mathrm{G} \mathrm{O}[\mathrm{mmol} / \mathrm{l}]$ & $\begin{array}{c}5.48 \pm 1.26 \\
\quad(5.26)\end{array}$ & $\begin{array}{c}5.76 \pm 1.06 \\
(5.43)\end{array}$ & \\
\hline G 120' [mmol/l] & $\begin{array}{c}6.48 \pm 2.91 \\
\quad(5.62)\end{array}$ & $\begin{array}{c}7.81 \pm 2.87 \\
(7.09)\end{array}$ & $p=0.043$ \\
\hline $\mathrm{DG}[\mathrm{mmol} / \mathrm{l}]$ & $\begin{array}{c}1.00 \pm 2.03 \\
(0.73)\end{array}$ & $\begin{array}{c}2.06 \pm 2.19 \\
\quad(1.80)\end{array}$ & $p=0.048$ \\
\hline Ins 0' [mU/l] & $\begin{array}{c}48.6 \pm 44.5 \\
(24.4)\end{array}$ & $\begin{array}{c}42.4 \pm 36.5 \\
(27.6)\end{array}$ & \\
\hline Ins 120' [mU/l] & $\begin{array}{c}164.3 \pm 150.1 \\
(108.9)\end{array}$ & $\begin{array}{c}203.9 \pm 175.8 \\
(138.1)\end{array}$ & \\
\hline DIns [mU/l] & $\begin{array}{c}115.7 \pm 147.2 \\
(50.1)\end{array}$ & $\begin{array}{c}161.5 \pm 165.3 \\
(92.8)\end{array}$ & \\
\hline IR (Ins 0'/G 0’) & $\begin{array}{c}0.506 \pm 0.499 \\
(0.281)\end{array}$ & $\begin{array}{c}0.423 \pm 0.373 \\
(0.254)\end{array}$ & \\
\hline $\mathrm{T}-\mathrm{C}[\mathrm{mmol} / \mathrm{l}]$ & $\begin{array}{c}5.35 \pm 1.08 \\
\quad(5.10)\end{array}$ & $\begin{array}{c}5.62 \pm 0.97 \\
(5.60)\end{array}$ & \\
\hline TAG $[\mathrm{mmol} / \mathrm{l}]$ & $\begin{array}{c}1.60 \pm 0.75 \\
(1.53)\end{array}$ & $\begin{array}{c}1.89 \pm 0.95 \\
(1.81)\end{array}$ & \\
\hline $\mathrm{HDL}-\mathrm{C}[\mathrm{mmol} / \mathrm{l}]$ & $\begin{array}{c}1.42 \pm 0.85 \\
\quad(1.21)\end{array}$ & $\begin{array}{c}1.21 \pm 0.26 \\
(1.22)\end{array}$ & \\
\hline LDL-C [mmol/l] & $\begin{array}{c}3.34 \pm 1.03 \\
\quad(3.06)\end{array}$ & $\begin{array}{c}3.56 \pm 0.92 \\
(3.55)\end{array}$ & \\
\hline Apo A $[\mathrm{mg} / \mathrm{dl}]$ & $\begin{array}{c}121.4 \pm 44.6 \\
(130.1)\end{array}$ & $\begin{array}{c}130.3 \pm 34.3 \\
(133.3)\end{array}$ & \\
\hline Apo B [mg/dl] & $\begin{array}{c}111.6 \pm 19.5 \\
(108.3)\end{array}$ & $\begin{array}{c}117.6 \pm 22.6 \\
(115.1)\end{array}$ & \\
\hline $\mathrm{U} A[\mu \mathrm{mol} / \mathrm{l}]$ & $\begin{array}{c}314.6 \pm 95.11 \\
(333.1)\end{array}$ & $\begin{array}{c}325.8 \pm 82.9 \\
(333.1)\end{array}$ & \\
\hline $\mathrm{Cr} O^{\prime}[\mathrm{nmol} / \mathrm{l}]$ & $\begin{array}{c}2.71 \pm 0.25 \\
\quad(2.67)\end{array}$ & $\begin{array}{c}2.94 \pm 0.21 \\
(2.98)\end{array}$ & $p=0.0025$ \\
\hline $\operatorname{Cr} 120^{\prime}[\mathrm{nmol} / \mathrm{l}]$ & $\begin{array}{c}3.48 \pm 0.65 \\
\quad(3.27)\end{array}$ & $\begin{array}{c}2.42 \pm 0.41 \\
\quad(2.53)\end{array}$ & $p<0.000$ \\
\hline $\mathrm{DCr}[\mathrm{nmol} / \mathrm{l}]$ & $\begin{array}{c}0.77 \pm 0.60 \\
(0.56)\end{array}$ & $\begin{array}{c}(-0.52) \pm 0.34 \\
(-0.45)\end{array}$ & $p<0.000$ \\
\hline
\end{tabular}


Table III. Glucose tolerance in the studied groups, according to OGTT results obtained

\begin{tabular}{|llccc|}
\hline & NGT & \multicolumn{3}{c|}{ Dysglycaemia } \\
\cline { 3 - 5 } & & IFG & IGT & T2DM \\
\hline Pos DCr $(n=24)$ & $n=14(58 \%)$ & $n=4(17 \%)$ & $n=4(17 \%)$ & $n=2(8 \%)$ \\
\hline $\operatorname{Neg} \operatorname{DCr}(n=24)$ & $n=11(46 \%)$ & $n=3(12.5 \%)$ & $n=7(29 \%)$ & $n=3(12.5 \%)$ \\
\hline
\end{tabular}

NGT - normal glucose tolerance, IFG - impaired fasting glycaemia, IGT-impaired glucose tolerance, T2DM - type 2 diabetes mellitus

Subjects with a negative difference of chromium concentrations during the OGTT (NegDCr) presented inverse correlations for CrO' and SBP (Figure 2), and CrO' and DBP (Figure 3).

\section{Discussion}

Investigators agree that widespread nutritional chromium deficiency of the human body is observed in developed countries. Contemporary diets may be low in this essential trace element, because of soil depletion, refined food, excessive sugar consumption, lack of exercise and obesity [9]. It is interesting that unequivocal $\mathrm{Cr}$ deficiency has been demonstrated only in humans on total parenteral nutrition with no chromium added. Paradoxically, morbidly obese patients may also demonstrate a nutritional deficiency, e.g. concerning minerals $[15,16]$.

A few studies have assessed serum chromium concentrations in a context of risk factors for CVD. Roussel et al. investigated the effects of hormonal replacement therapy (HRT) on chromium status and metabolic parameters in French postmenopausal females. They observed lower serum $\mathrm{Cr}$ concentration in untreated women $(1.35 \pm 0.16 \mathrm{nmol} / \mathrm{l})$ compared with HRT-receiving females $(1.93 \pm 0.16$ $\mathrm{nmol} / \mathrm{l}$ ) improving their carbohydrate and lipid metabolism; otherwise both groups presented decreased levels as far as our study population is concerned [17].

Another unique study presented chromium status and glucose tolerance in Saudi men with and without CVD. The authors observed higher serum

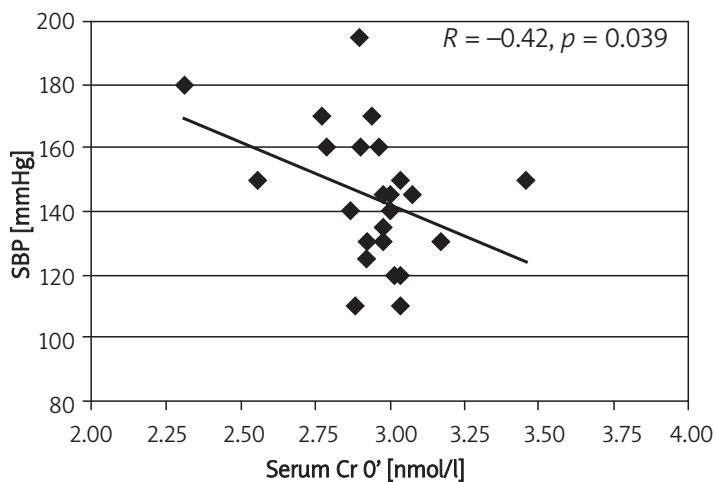

Figure 2. The correlation between SBP and CrO' in the NegDCr group, described by Spearman coefficient, $\mathrm{R} ; p<0.05$ chromium concentrations as compared with our studied subjects. This could be explained by either possible different nutrients intake or lower BMI (overweight) of that population in contrast to higher $\mathrm{BMI}$ (obese) of our study group. Even then, a worldwide tendency to meet the lowest serum $\mathrm{Cr}$ in diabetic patients, among studied normal glucose tolerance and impaired glucose tolerance (IGT) and diabetic Saudi subjects, was obvious. Alissa et al. found serum chromium (OR 0.99, 95\% Cl 0.985$0.995, p<0.0001)$, urinary $\mathrm{Cr}(\mathrm{OR} 0.988,95 \% \mathrm{Cl}$ $0.981-0.995, p<0.001)$ and plasma glucose (OR 1.127, 95\% Cl 1.0-1.269, $p<0.05$ ) to be independently associated with the presence of coronary heart disease (CHD) [18].

Despite a lack of studies on serum chromium status, the influence of the essential trace element on metabolic risk factors for CVD is of significant interest to clinicians.

There are numerous studies evaluating the effects of chromium supplementation on carbohydrate and lipid metabolism parameters in humans and in experimental studies. Papers document the improved glucose tolerance and lipid metabolism in type 2 diabetics [19]. Naturally occurring compounds, such as chromium and polyphenols from cinnamon improve all signs of the metabolic syndrome in type 2 diabetic patients as well [20]. These findings conflict with studies showing no effects on carbohydrate metabolism and serum lipid concentrations, especially in patients without type 2 diabetes [21]. There were no changes in insulin sensitivity, serum lipids and body com-

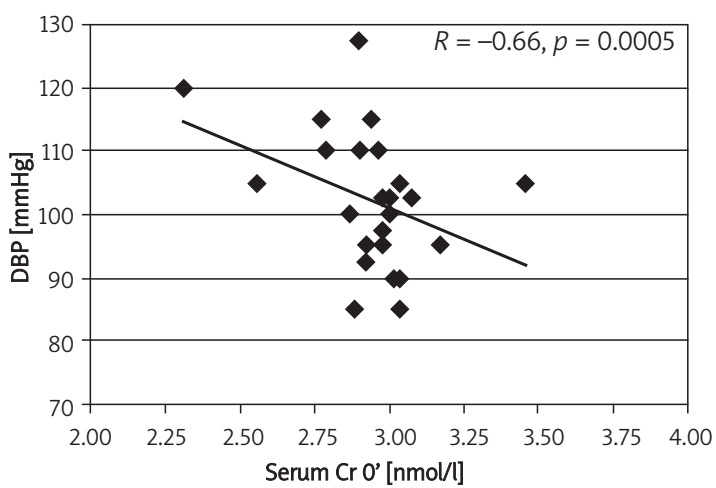

Figure 3. The correlation between DBP and CrO' in the NegDCr group, described by Spearman coefficient, $\mathrm{R} ; p<0.05$ 
position after chromium supplementation in healthy elderly subjects [22]. Chromium supplementation did not improve key features of the metabolic syndrome in non-diabetic obese patients, either $[23,24]$.

Trying to explain the above-mentioned results, it was proposed that diabetic subjects may have altered chromium metabolism, as both absorption and excretion may be higher compared with nondiabetics [25].

Among supplementation studies we have found one paper concerning an influence of 12 -week chromium supplementation on metabolic characteristics in moderately obese women under an exercise program. The authors assessed, among other things, some biochemical parameters, including plasma chromium, before (fasting) and $1 \mathrm{~h}$ and $2 \mathrm{~h}$ after a standardized 300-kcal 74-g carbohydrate meal. Volpe et al. did not note any changes for plasma $\mathrm{Cr}$ concentrations in response to a high-carbohydrate meal, which the present study does report during the OGTT. The authors explained this part of their investigation with neither diabetes nor pre-diabetes diagnosed in studied females [26].

Frauchiger, Wenk and Colombani focused on acute chromium supplementation during the test meal, providing $75 \mathrm{~g}$ of available carbohydrates (imitating the OGTT). The authors observed a beneficial effect on postprandial glucose level in most (called responders) but not all subjects. The two ways of serum chromium utilization we have discovered might explain the results of that study; our investigated NegDCr group could reflect their "non-responders" [27].

There are no data reflecting serum chromium status during the OGTT among published studies yet. Our preliminary results suggest that the studied centrally obese persons may differ in chromium metabolism, increasing or decreasing the difference of serum chromium concentrations ( $\mathrm{DCr}$ ) during the OGTT. In persons "consuming" chromium during the OGTT (NegDCr group) decreased fasting $\mathrm{Cr}$ is related to elevated both systolic and diastolic blood pressure. These subjects presented higher postprandial glucose (G 120') levels. The tendencies to increase T-C, TAG and LDL-C, and decrease HDL-C, were observed in the group as well. These findings are in agreement with the scarce data concerning relationships between decreased serum $\mathrm{Cr}$ and increased risk for CHD [18].

Limitations of our study might include the lack of a control group with normal waist and body mass index subjects. It could be interesting if a dispersion of serum chromium concentration during the OGTT is a feature of centrally obese subjects or could characterize humans in general.

Summing up, apart from anthropometric characteristics of obesity, metabolic parameters of the studied subjects could be more or less associated with serum chromium status. Our studied NegDCr persons seem to be more advanced in metabolic disturbances compared with the PosDCr group.

Regarding features of the metabolic syndrome, the way of chromium utilization may affect blood pressure and glucose metabolism especially. This finding might be applied to clinical practice if it is confirmed in further investigations.

In conclusion, our data, documenting contradictory changes of serum chromium concentrations during the OGTT, could explain the different metabolic results for chromium supplementation found in the cited literature. Persons who utilize chromium intensively during the OGTT might require more trivalent chromium for the possible benefit from this factor.

\section{Acknowledgments}

The research was supported by Poznan University of Medical Sciences, Poland. No conflict of interest was declared in relation to this work.

\section{References}

1. Alberti KG, Eckel RH, Grundy SM, et al. Harmonizing the metabolic syndrome. A joint interim statement of the International Diabetes Federation Task Force on Epidemiology and Prevention; National Heart, Lung, and Blood Institute; American Heart Association; World Heart Federation; International Atherosclerosis Society; and International Association for the Study of Obesity. Circulation 2009; 120: 1640-5.

2. International Diabetes Federation. The IDF consensus worldwide definition of the metabolic syndrome. 2005; www.idf.org/webdata/docs/Metac_syndrome_def.pdf.

3. Delavari A, Kelishadi R, Forouzanfar MH, Safaei A, Birjandi F, Alikhani S. The first cut-off points for generalized and abdominal obesity in predicting lipid disorders in a nationally representative population in the Middle East: The National Survey of Risk Factors for NonCommunicable Diseases of Iran. Arch Med Sci 2009; 5: 542-9.

4. Michalska M, Gluba A, Mikhailidis DP, et al. The role of polyphenols in cardiovascular disease. Med Sci Monit 2010; 16: RA110-9.

5. Vincent JB. Mechanisms of chromium action: lowmolecular-weight chromium-binding substance. J Am Coll Nutr 1999; 18: 6-12.

6. Vincent JB. Elucidating a biological role for chromium at a molecular level. Acc Chem Res 2000; 33: 503-10.

7. Vincent JB. The biochemistry of chromium. J Nutr 2000; 130: 715-8.

8. Yang JM, Lewandrowski KB. Trace elements, vitamins and nutrition. In: Clatchey KD. Clinical laboratory medicine. $2^{\text {nd }}$ ed. Lippincott Williams \& Wilkins, Philadelphia 2002; 452.

9. Davies S, McLaren Howard J, Hunnisett A, Howard M. Agerelated decreases in chromium levels in 51,665 hair, sweat and serum samples from 40,872 patients - implications for the prevention of cardiovascular disease and type II diabetes mellitus. Metabolism 1997; 46: 469-73. 
10. Cefalu WT, Hu FB. Role of chromium in human health and in diabetes. Diabetes Care 2004; 27: 2741-51.

11. Morris BW, MacNeil S, Hardisty CA, Heller S, Burgin C, Gray TA. Chromium homeostasis in patients with type II (NIDDM) diabetes. J Trace Elem Med Biol 1999; 13: 57-61.

12. Trow LG, Lewis J, Greenwood RH, et al. Lack of effect of dietary chromium supplementation on glucose tolerance, plasma insulin and lipoprotein levels in patients with type 2 diabetes. Int J Vitam Nutr Res 2000; 70: 14-8.

13. Althuis MD, Jordan NE, Ludington EA, Wittes JT. Glucose and insulin responses to dietary chromium supplements: a meta-analysis. Am J Clin Nutr 2002; 76: 148-55.

14. Raport of a Who Study Group. Prevention of diabetes mellitus: World Health Org., Geneva 1994. WHO Tech Rep Ser, No 844.

15. Kaidar-Person O, Person B, Szomstein S, Rosenthal RJ. Nutritional deficiencies in morbidly obese patients: a new form of malnutrition? Part B: minerals. Obes Surg 2008; 18: 1028-34.

16. Schweiger C, Weiss R, Berry E, Keidar A. Nutritional deficiencies in bariatric surgery. Obes Surg 2010; 20: 193-7.

17. Roussel AM, Bureau I, Favier M, Polansky MM, Bryden NA, Anderson RA. Beneficial effects of hormonal replacement therapy on chromium status and glucose and lipid metabolism in postmenopausal women. Maturitas 2002; 42: 63-9.

18. Alissa EM, Bahjri SM, Ahmed WH, Al-Ama N, Ferns GA. Chromium status and glucose tolerance in Saudi men with and without coronary artery disease. Biol Trace Elem Res 2009; 131: 215-28.

19. Bahijri SM, Mufi AM. Beneficial effects of chromium in people with type 2 diabetes, and urinary chromium response to glucose load as a possible indicator of status. Biol Trace Elem Res 2002; 85: 97-109.

20. Anderson RA. Chromium and polyphenols from cinnamon improve insulin sensitivity. Proc Nutr Soc 2008; 67: 48-53.

21. Balk EM, Tatsioni A, Lichtenstein AH, Lau J, Pittas AG. Effect of chromium supplementation on glucose metabolism and lipids: a systematic review of randomized controlled trials. Diabetes Care 2007; 30: 2154-163.

22. Amato P, Morales AJ, Yen SS. Effects of chromium picolinate supplementation on insulin sensitivity, serum lipids, and body composition in healthy, nonobese, older men and women. J Gerontol A Biol Sci Med Sci 2000; 55: M260-3.

23. Iqbal N, Cardillo S, Volger S, et al. Chromium picolinate does not improve key features of metabolic syndrome in obese nondiabetic adults. Metab Syndr Relat Disord 2009; 7: 143-50.

24. Ali A, Ma Y, Reynolds J, Wise JP, Inzucchi SE, Katz DL. Chromium effects on glucose tolerance and insulin sensitivity in people at risk for diabetes. Endocr Pract 2010; 1: 1-21.

25. Anderson RA, Cheng N, Bryden NA, Polansky MM, Chi J, Feng J. Elevated intakes of supplemental chromium improve glucose and insulin variables in individuals with type 2 diabetes. Diabetes 1997; 46: 1786-91.

26. Volpe SL, Huang HW, Larpadisorn K, Lesser II. Effect of chromium supplementation and exercise on body composition, resting metabolic rate and selected biochemical parameters in moderately obese women following an exercise program. J Am Coll Nutr 2001; 20: 293-306.

27. Frauchiger MT, Wenk C, Colombani PC. Effects of acute chromium supplementation on postprandial metabolism in healthy young men. J Am Coll Nutr 2004; 23: 351-7. 